\title{
GAMBARAN ANEMIA BERDASARKAN GIZI DAN LAMA MENSTRUASI DI SMAN 1 PARONGPONG 2019
}

\section{${ }^{1}$ Barbara MAD, ${ }^{2}$ Intan K, ${ }^{3}$ Wulandari RG}

\begin{abstract}
ABSTRAK
Latar Belakang: Remaja putri merupakan salah satu kelompok yang sangat rawan menderita anemia, karena remaja putri sedang berada pada masa pubertas maka kebutuhan zat besi untuk menyeimbangkan perkembangan tubuh semakin besar. Menurut World Health Organization, anemia pada remaja putri sampai saat ini masih cukup tinggi yaitu 40-88\%.

Tujuan Penelitian: Untuk mengetahui gambaran kejadian anemia pada remaja putri berdasarkan status gizi dan lama menstruasi di SMAN 1 Parongpong tahun 2019.

Metode Penelitian: Jenis penelitian ini adalah deskriptif dengan pendekatan cross sectional. Teknik pengambilan sampel menggunakan stratified random sampling, sampel yang didapatkan yaitu 230 remaja putri di SMAN 1 Parongpong tahun 2019. Penelitian ini dilakukan dengan cara observasi secara langsung dan kuesioner. Penelitian ini menggunakan analisis univariat yaitu dengan menyajikan data dalam bentuk tabel distribusi frekuensi.

Hasil: Sebagian besar remaja putri di SMAN 1 Parongpong tidak mengalami anemia sebesar $67,0 \%$, sebagian besar remaja putri di SMAN 1 Parongpong tidak mengalami anemia dengan IMT normal yaitu sebesar 68,8\%, dan sebagian besar remaja putri di SMAN 1 Parongpong mengalami anemia ringan dengan lama menstruasi lebih dari 7 hari (hipermenore) yaitu sebanyak $80,8 \%$.

Simpulan: Hampir setengah responden mengalami kejadian anemia ringan, sebagian besar responden mengalami anemia ringan dengan IMT underweight (kurus), dan hampir seluruhnya responden mengalami anemia ringan dengan lama menstruasi hipermenore $(>7$ hari).
\end{abstract}

Kata Kunci: Anemia, Status Gizi, Lama Menstruasi

\section{PENDAHULUAN}

Masa remaja banyak permasalahan yang sering muncul terutama permasalahan dalam bidang kesehatan, salah satunya anemia. Di seluruh dunia terutama di Negara berkembang anemia merupakan masalah kesehatan yang masih sering terjadi di masyarakat, kejadian anemia banyak terjadi terutama pada usia remaja baik kelompok pria maupun wanita(WHO, 2013).

Anemia sangat sering terjadi dalam kehidupan remaja, khususnya remaja putri. Hal inidapat terjadi karena remaja putrid sedang berada pada masa pubertas maka kebutuhan zat besi untuk menyeimbangkan perkembangan tubuh semakin besar. Selain itu, beban ganda yang remaja putri diemban adalah mengalami menstruasi, yang berarti juga remaja putri 
memiliki kebutuhan untuk menggantikan zat besi yang hilang bersama keluarnya darah saat menstruasi (Briawan, 2014).Pentingnyakecukupan status gizi terutama pada remaja sampai saat ini masih menjadi suatu permasalahan yang serius karena program penanggulangan kesehatan pada remaja tidak berjalan secara optimal. Berbagai permasalahan gizi yang dialami oleh remaja diantaranya kekurangan energi protein, kekurangan vitamin A, anemia gizi besi dan kekurangan yodium (Kemenkes RI, 2010).

Anemia pada remaja putrid sampai saat ini masih cukup tinggi, menurut World Health Organization (WHO, 2013), prevalensi anemia dunia berkisar 40-88\% pada tahun 2012 . Menurut WHO (2013), angka kejadian anemia pada remaja putri di negara-negara berkembangsekitar 53,7\% dari semua remaja putri dan angka anemia gizi besi di Indonesia sebanyak 72,3\% pada tahun 2012. Menurut Riset Kesehatan Dasar (2013), menunjukkan anemia gizi besi pada remaja putri 16 - 18 tahun masih merupakan masalah kesehatan dengan prevalensi sebesar 22,7\% pada tahun 2013 (Kemenkes RI, 2013). Kekurangan besi pada remaja mengakibatkan pucat, lemah, letih, pusing, danmenurunnyakonsentrasibelajar.BerdasarkanhasilrisetStudi Baseline danRisetFormatif yang dilakukanolehKementerianKesehatan 2016terdapat 52\% remajaputrimengalami anemia pada tahun 2016 (Kemenkes RI, 2017). Sejak tahun 2013 di Jawa Barat terdapat 26,4\% remaja putri mengalami anemia (Riskesdas, 2013).

Menurut data Kemenkes Provinsi Jawa Barat tahun (2016) pemberian cakupan tablet fe di Bandung Barat sangat rendah dari target pemerintah yaitu hanya 83,7\% dari $90 \%$ sehingga banyak menyebabkan anemia pada remaja. Tingkat prevalensi kejadian anemia di Kabupaten Bandung Barat dan Kabupaten Purwakarta termasuk permasalahan kesehatan masyarakat kategori berat. Menurut data Dinas Kesehatan Kabupaten Bandung Barat dan Dinas Kesehatan Provinsi Jawa Barat terdapat anemia sebanyak 28\% pada remaja putri di Parongpong pada tahun 2018. Sedangkan di SMAN 1 Parongpong data anemia pada remaja putri sebanyak $24 \%$ pada tahun 2017 (Data Puskesmas Parongpong, 2017).

Upaya penanggulangan anemia gizi diprioritaskan kepada kelompok rawan yaitu ibu hamil, balita, anak usia sekolah dan wanita usia subur termasuk remaja putri dan pekerja wanita. Terjadinya defisiensi besi pada wanita, antara lain disebabkan jumlah zat besi yang di absorbsi sangat sedikit, tidak cukupnya zat besi yang masuk karena rendahnya bioavalibilitas makanan yang mengandung besi atau kenaikan kebutuhan besi, periode pertumbuhan dan pada waktu menstruasi. Penanganan defisiensi besi dengan pemberian suplementasi tablet besi merupakan cara yang paling efektif untuk meningkatkan kadar 
Fe/besi dalam jangka waktu yang pendek. Untuk penanggulangan kejadian anemia pada remaja pemerintah melakukan penjaringan terhadap kegiatan kesehatan di sekolah mengacu pada peraturan bersama 4 menteri No 6/X/PB/2014 No 73 TAHUN 2014, No 41 tahun 2014, dan No 81 tahun 2014 yaitu Kementerian Pendidikan dan Kebudayaan, Kementerian Kesehatan, Kementerian Agama dan Kementerian Dalam Negeri berisi tentang perlu adanya peningkatan koordinasi Puskesmas dan Usaha Kesehatan (UKS) yang ada di sekolah serta melaksanakan pencegahan anemia pada remaja putri dengan pemberian Tablet tambah darah mulai tahun ajaran 2016/2017 (Rikesdas, 2013).

Berdasarkan penelitian yang dilakukan oleh Reni Saswita pada tahun 2016 dengan judul "Gambaran Lama Menstruasi dan Status Gizi dengan Kejadian Anemia pada Remaja Putri di SMK Bina Cipta Palembang Tahun 2016", menunjukkan hasil sebagian besar responden $(53,8 \%)$ mengalami anemia ringan sekali, sebagian besar responden $(61,6 \%)$ dengan lama menstruasi 7 hari dan sebagian besar responden (67,3\%) IMT pada kategori normal. Dari kelompok responden yang mengalami anemia baik ringan sekali, ringan dan sedang sebagian besar adalah responden dengan lama menstruasi 7 hari yaitu 57,1\%, 37,5\% dan $85,7 \%$. Dari kelompok responden yang mengalami anemia ringan sekali, sebagian besar adalah responden dengan IMT normal yaitu 71,4\%, dan dari kelompok responden yang mengalami anemia ringan dan sedang, sebagian besar adalah responden dengan IMT kurang yaitu $62,5 \%$ dan $57,1 \%$.

Selanjutnya, darihasilpenelitian yang dilakukanoleh Abdul Basith, Rismia Agustina, dan Noor Diani dengan judul "Faktor-Faktor yang Berhubungan dengan Kejadian Anemia pada Remaja Putri tahun 2016", hasil penelitian responden memiliki panjang siklus menstruasi yang normal, lebih dari setengah (52\%), sedangkan lama dan panjang siklus menstruasi yang tidak normal merupakan salah satu jenis gangguan menstruasi lama dan panjang siklus menstruasi yang tidak normal merupakan salah satu jenis gangguan menstruasi. Hasil analisis lama siklus menstruasi dengan kejadian anemia dengan uji fisher exact didapatkan p-value sebesar 0,064>0,05 yang berarti H0 di terima, sehingga tidak terdapat hubungan antara status gizi dengan kejadian anemia pada remaja putri di SMP Negeri 4 Banjarbaru. Sedangkan kejadian anemia paling banyak terjadi pada remaja yang memiliki status gizi normal dengan persentase sebesar $44 \%$. Hasil analisis hubungan status gizi dengan kejadian anemia dengan uji fisher exact didapatkan p-value sebesar 0,064 > 0,05 yang berarti H0 diterima, sehingga tidak terdapat hubungan antara status gizi dengan kejadian anemia pada remaja putri di SMP Negeri 4 Banjarbaru. 


\section{METODE}

Rancangan dalam penelitian ini menggunakan metode penelitian desktiptif kuantitatif yang mana penelitian hanya akan menggambarkan atau mendesktiptifkan variabel tertentu dalam suatu penelitian tanpa mencari suatu hubungan antara variabel (Setiawan dan Saryono, 2010). Dalam penelitian ini menggunakan pendekatan dengan metode cross sectional dikarenakan penyusunan ini merupakan penyusunan penelitian dengan melakukan pengukuran dan pengamatan pada saat yang bersamaan (satu waktu) (Notoatmodjo, 2010).

Teknik pengambilan sampel menggunakan stratified random sampling, sampel yang didapatkan yaitu 230 remaja putri di SMAN 1 Parongpong tahun 2019. Penelitian ini dilakukan dengan cara observasi secara langsung dan kuesioner. Penelitian ini menggunakan analisis univariat yaitu dengan menyajikan data dalam bentuk tabel distribusi frekuensi.

\section{HASIL}

Tabel 1Distribusi Frekuensi Responden berdasarkan Kejadian Anemia

\begin{tabular}{llcc}
\hline NO & \multicolumn{1}{c}{ Anemia } & F & \% \\
\hline 1 & Ringan & 73 & $32,0 \%$ \\
\hline 2 & Sedang & 3 & $1,0 \%$ \\
\hline 3 & Berat & 0 & $0 \%$ \\
\hline 4 & Tidak Anemia & 154 & $67,0 \%$ \\
\hline & Jumlah & 230 & $100 \%$
\end{tabular}

Berdasarkan tabel 4.1.1 di atas dapat diketahui bahwa sebagian besar remaja putri di SMAN 1 Parongpong tidak mengalami anemia sebesar 67,0\%.

Tabel 2Distribusi Frekuensi Repsonden berdasarkanStatus Gizi (IMT)

\begin{tabular}{cccc}
\hline No & \multicolumn{1}{c}{ IMT } & F & \% \\
\hline 1 & Obesitas (>27) & 1 & $0,4 \%$ \\
\hline 2 & Overweight $(24-27)$ & 14 & $6,1 \%$ \\
\hline 3 & Normal $(18-23)$ & 134 & $58,3 \%$ \\
\hline 4 & Underweight $(<17)$ & 81 & $35,2 \%$ \\
\hline & Jumlah & 230 & $100 \%$
\end{tabular}

Berdasarkan tabel 4.1.2 di atas dapat diketahui bahwa sebagian besar remaja putri di SMAN 1 Parongpong yang memiliki IMT normal sebesar 58,3\%.

Tabel 3Distribusi Frekuensi Responden berdasarkan Lama Menstruasi 


\begin{tabular}{clcc}
\hline No & Lama Menstruasi & F & \% \\
\hline 1 & $\begin{array}{l}\text { Hiperminore } \\
\text { (> 7 hari) }\end{array}$ & 92 & $40,0 \%$ \\
\hline 2 & $\begin{array}{l}\text { Hipomenore } \\
\text { (<3 hari) }\end{array}$ & 32 & $14,0 \%$ \\
\hline 3 & Normal (4-7 hari) & 106 & $46,0 \%$ \\
\hline$\quad$ Jumlah & 230 & $100 \%$ \\
\hline
\end{tabular}

Berdasarkan tabel 4.1.3 di atas dapat diketahui bahwa hampir setengahnya remaja putri di SMAN 1 Parongpong mengalami lama menstruasi normal yaitu sebesar 46,0\%.

Tabel 4 Distribusi Frekunesi Kejadian Anemia Berdasarkan Status Gizi (IMT)

\begin{tabular}{|c|c|c|c|c|c|c|}
\hline \multirow[b]{2}{*}{ No } & \multirow[b]{2}{*}{ Anemia } & \multicolumn{4}{|c|}{ Status Gizi (IMT) } & \multirow[b]{2}{*}{ Jumlah } \\
\hline & & Obesitas & Overweight & normal & underweight & \\
\hline \multirow[t]{3}{*}{1} & Ringan & & & & & \\
\hline & $f$ & - & 2 & 27 & 44 & 73 \\
\hline & $\%$ & - & 2,8 & 37,0 & 60,3 & 100,0 \\
\hline \multirow[t]{3}{*}{2.} & Sedang & & & & & \\
\hline & $f$ & - & - & 1 & 2 & 3 \\
\hline & $\%$ & - & - & 33,3 & 66,7 & 100,0 \\
\hline \multirow[t]{3}{*}{3.} & Berat & & & & & \\
\hline & $f$ & - & - & - & - & - \\
\hline & $\%$ & - & - & - & - & - \\
\hline \multirow[t]{6}{*}{4.} & Tidak anemia & & & & & \\
\hline & $f$ & 1 & 12 & 106 & 35 & 154 \\
\hline & $\%$ & 0,7 & 7,8 & 68,8 & 22,7 & 100,0 \\
\hline & Total & & & & & \\
\hline & $f$ & 1 & 14 & 134 & 81 & 230 \\
\hline & $\%$ & 0,7 & 6,1 & 58,3 & 35,2 & 100,0 \\
\hline
\end{tabular}

Berdasarkan tabel 4.1.4 di atas dapat diketahui bahwa sebagian besar remaja putri di SMAN 1 Parongpong mengalami anemia dengan IMT underweight (kurus) yaitu sebesar $60,3 \%$, sedangkan sebagian besar remaja putri di SMAN 1 Parongpong tidak mengalami anemia dengan IMT normal yaitu sebesar $68,8 \%$.

Tabel 5 Distribusi Frekuensi Kejadian Anemia Berdasarkan Lama Menstruasi

\begin{tabular}{cccccc}
\hline & & \multicolumn{4}{c}{ Lama Menstruasi } \\
\cline { 3 - 6 } No & Anemia & Hipermenore & Hipomenore & Normal & Jumlah \\
\hline 1 & Ringan & & & & 12 \\
\hline & $\mathrm{f}$ & 59 & 2 & 16,4 & 100,0 \\
\hline & $\%$ & 80,8 & 2,8 & & \\
\hline 2. & Sedang & & & 1 & 3 \\
\hline & $\mathrm{f}$ & 2 & - & 33,3 & 100,0 \\
\hline & $\%$ & 66,7 & - & &
\end{tabular}




\begin{tabular}{|c|c|c|c|c|c|}
\hline & $\mathrm{f}$ & - & - & - & - \\
\hline & $\%$ & - & - & - & - \\
\hline \multicolumn{6}{|c|}{ Tidak anemia } \\
\hline & $\mathrm{f}$ & 31 & 30 & 93 & 154 \\
\hline & $\%$ & 21,0 & 19,0 & 60,0 & 100,0 \\
\hline \multicolumn{6}{|c|}{ Total } \\
\hline & $\mathrm{f}$ & 92 & 32 & 106 & 230 \\
\hline & $\%$ & 40,0 & 14,0 & 46,0 & 100,0 \\
\hline
\end{tabular}

Berdasarkan tabel 4.1.5 di atas dapat diketahui bahwa sebagian besar remaja putri di SMAN 1 Parongpong mengalami anemia ringan dengan lama menstruasi lebih dari tujuh hari (hipermenore) yaitu sebanyak 80,8\%, sedangkan sebagian besar remaja putri d SMAN 1 Parongpong tidak anemia dengan lama menstruasi normal yaitu sebesar 60,0\%.

\section{PEMBAHASAN}

\section{Kejadian Anemia}

Berdasarkan hasil pemeriksaan kadar $\mathrm{Hb}$ menggunakan alat bantu $\mathrm{Hb}$ digital haemometer, ditemukan sebagian besar responden tidak mengalami anemia sebanyak 154 orang $(67 \%)$, sebagian responden mengalami anemia ringan sebanyak 72 orang $(32,0 \%)$ dan sebagian responden mengalami anemia sedang sebanyak 3 orang $(1,0 \%)$.

Berdasarkan penelitian ini benyak responden tidak mengalami anemia. Kebanyakan responden tidak mengalami anemia dikarenakan status gizi dan lama menstruasinya normal. Pernyataan ini sesuai dengan teori (Fikawati, 2017) Status giziada hubungan antara status gizi dan kejadian anemia. Remaja yang status gizinya kurus mempunyai resiko mengalami anemia 1,5 kali dibandingkan remaja yang status gizinya normal (Fikawati, 2017). Pernyataan tersebut juga sesuai dengan teori (Arisaman, 2010) Kehilangan darah secara kronis (menstruasi). Pada laki-laki kehilangan darah kronis dapat saja disebabkan oleh proses perdarahan akibat suatu penyakit (trauma), atau dikarenakan sedang dalam pengobatan suatu penyakit. Sedangkan pada wanita, terjadi kehilangan darah secara alamiah setiap bulannya yaitu menstruasi. Jika pada saat menstruasi terjadi pengeluaran darah yang terlalu banyak maka akan menyebabkan anemia pada wanita tersebut (anemia zat besi) (Arisman, 2010).

Berdasarkan penelitian Suryani dkk (2015) dengan judul "Analisis Pola Makan dan Anemia Gizi Besi pada Remaja Putri”, menyimpulkan bahwa anemia dapat terjadi pada remaja dikerenakan asupan nutrisi yang tidak dapat mencukupi gizi remaja dan juga remaja yang perdarahan menstruasi berat dapat berisiko terjadinya anemia. Penelitian lain yang 
sesuai dengan hasil penelitian ini, yaitu penelitian Indartanti dkk (2014) dengan judul "Hubungan Status Gizi dengan Kejadian Anemia pada remaja putri", penelitian ini menyimpulkan bahwa anemia adalah menurunnya jumlah hemoglobin dari batas normal, anemia dapat dipengaruhi karena kurangnya asupan zat besi dan status gizi yang kurang (underweight).

Dari hasil penelitian ini, peneliti berasumsi bahwa anemia tidak akan terjadi pada remaja putri, jika remaja putri tersebut memiliki status gizi yang normal dan lama menstruasinya juga normal. Remaja putri tersebut harus menjaga status gizinya agar seimbang dan harus mengkonsumsi tablet Fe jika lama menstruasinya lebih dari 7 hari untuk menghindari anemia.

\section{Kejadian Anemia berdasarkan Status Gizi (IMT)}

Berdasarkan hasil pengukuran diketahui berat badan dan tinggi badan responden kemudian dilakukan perhitungan Indeks Massa Tubuh (IMT) didapatkan sebagian besar responden yang IMTnya underweight mengalami anemia ringan yaitu sebanyak 44 orang $(60,3 \%)$ dan mengalami anemia sedang sebanyak 2 orang $(66,7 \%)$.

Sebagian besar IMT responden pada kategori underweight adalah yang paling banyak mengalami anemia baik anemia ringan $m$ aupun anemia sedang. Hasil penelitian ini sesuai dengan peryantaan Fikawati (2017) Remaja dengan status gizi kurus mempunyai resiko mengalami anemia lebih besar dibandingkan remaja yang status gizinya normal (remaja kurus mempunyai resiko 1,5 kali dibandingkan remaja yang normal). Hal tersebut juga didukung oleh studi penelitian yang dilakukan Briawan dan Handiansyah pada tahun 2010 bahwa status gizi normal dan lebih bukan faktor anemia. Pada perempuan dengan IMT $>18,5 \mathrm{~kg} / \mathrm{m}^{2}$ cenderung tidak anemia dibandingkan perempuan dengan IMT $<18,5 \mathrm{~kg} / \mathrm{m}^{2}$ yang lebih banyak mengalami anemia.

Berdasarkan hasil penelitian ditemukan 44 orang responden menderita anemia yaitu sebanyak 41 responden mengalami anemia ringan dan 3 orang responden menderita anemia sedang diduga disebabkan oleh status gizi yang kurang dimana hasil perhitungan IMT < 18,5, hal ini sesuai pernyataan Naristasari (2015), status gizi dapat mempengaruhi kejadian anemia, apabila asupan gizi dalam tubuh kurang, hal ini menyebabkan kebutuhan gizi dalam tubuh tidak terpenuhi terutama kebutuhan gizi seperti zat besi dimana zat besi merupakan salah satu komponen terpenting dalam pembentukan hemoglobin. Berkurangnya asupan nutrisi dan zat besi dalam tubuh seseorang akan menyebabkan berkurangnya bahan pembentuk sel darah 
merah, sehingga sel darah merah tidak dapat melakukan fungsinya dalam mensuplai oksigen keseluruh tubuh sehingga mengakibatkan terjadinya anemia.

Hasil penelitian ini sejalan dengan hasil penelitian Reni (2016), dengan judul “Gambaran Lama Menstruasi Dan Status Gizi Dengan Kejadian Anemia Pada Remaja Putri Di Smk Bina Cipta Palembang Tahun 2016”, menyimpulkan mahasiswi yang mengalami anemia ringan dan sedang, sebagian besar adalah responden dengan IMT kurang yaitu 62,5\% dan 57,1\%. Hasil penelitian ini juga sejalan dengan hasil penelitian Suchi dkk (2018) dengan judul "Hubungan Antara Status Gizi Dan Pola Menstruasi Dengan Kejadian Anemia Pada Mahasiswi Prodi DIII Kebidanan Universitas Muslim Indonesia”, menyimpulkan bahwa mahasiswi yang mengalami anemia dengan status gizi sangat kurus sebanyak 11 orang $18,96 \%$ mengalami anemia dan 2 orang $(3,46 \%)$ tidak mengalami anemia, pada responden dengan status gizi kurus diperoleh sebanyak 8 orang $(13,79 \%)$ mengalami anemia dan 4 orang $(6,90 \%)$ tidak mengalami anemia.

Hasil penelitian ini sejalan dengan hasil penelitian Nur dkk (2017) dengan judul "Skrining Dan Determinan Kejadian Anemia Pada Remaja Putri Sma Negeri 3 Kendari Tahun 2017", menyimpulkan bahwa remaja putri yang mengalami anemia yaitu dari 34 responden dengan status gizi kurus sebanyak $61,8 \%$ responden yang menderita anemia dan $38,2 \%$ responden tidak menderita anemia.Hasil penelitian ini juga sejalan dengan hasil penelitian Abidin, dkk (2012), dengan judul "Hubungan Indeks Massa Tubuh (IMT) Dengan Kejadian Anemia Pada Remaja Putri di SMA Kifayatul Achyar Wilayak Kec. Cibiru Bandung”, menyimpulkan sebagian besar remaja putri tergolong dalam IMT kurus mengalami anemia ringan. Berdasarkan hasil penelitian ditemukan 4 orang responden menderita anemia ringan sekali dan 2 orang responden menderita anemia ringan serta 4 orang responden menderita anemia sedang diduga perhitungan IMT $<18,5$ yang mengkategorikan status gizi yang kurang, hal ini sesuai dengan pernyataan.

Berdasarkan hasil penelitian ini, peneliti berasumsi bahwa sebagian besar remaja putri mengalami anemia dikarenakan status gizinya kurang. Oleh kerena itu, diperlukan dukungan dan pendidikan kesehatan yang dibutuhkan dalam proses memperbaiki status gizi pada remaja untuk mencegah terjadinya anemia akibat status gizi yang kurang.

\section{Kejadian Anemia berdasarkan Lama Menstruasi}

Berdasarkan hasil kuesioner yang diberikan kepada responden diketahui bahwa hampir seluruhnyaresponden yang lama menstruasinya $>7$ hari (hipermenore) megalami 
anemia ringan yaitu sebanyak 59 orang $(80,8 \%)$ dan mengalami anemia sedang sebanyak 2 orang $(66,7 \%)$.

Sebagian besar responden yang lama menstruasi $>7$ hari (hipermenore) adalah responden yang paling banyak mengalami anemia ringan maupun anemia sedang. Hasil penelitian ini sesuai dengan pernyataan Arisman (2010) penyebab anemia yaitu Kehilangan darah secara kronis (menstruasi) Pada laki-laki kehilangan darah kronis dapat saja disebabkan oleh proses perdarahan akibat suatu penyakit (trauma), atau dikarenakan sedang dalam pengobatan suatu penyakit. Sedangkan pada wanita, terjadi kehilangan darah secara alamiah setiap bulannya yaitu menstruasi. Jika pada saat menstruasi terjadi pengeluaran darah yang terlalu banyak maka akan menyebabkan anemia pada wanita tersebut (anemia zat besi) (Arisman, 2010).Sepanjang usia reproduksi, wanita akan mengalami kehilangan darah pada setiap bulannya melalui peristiwa menstruasi. Beberapa penelitian telah membuktikan bahwa jumlah darah yang hilang selama satu periode menstruasi berkisar antara 20-25 cc. Jumlah ini menunjukan bahwa kehilangan zat besi sebesar 12,5-15 mg/bulan, atau sama dengan 0,40,5 mg sehari. Jika jumlah tersebut ditambah dengan kehilangan basal, jumlah total zat besi yang hilang sebesar 1,25 mg per hari.

Selain itu hasil penelitian ini sesuai dengan pernyataan Arisman (2010) Saat menstruasi terjadi pengeluaran darah dari dalam tubuh. Hal ini menyebabkan zat besi yang terkandung dalam hemoglobin berkurang.Salah satu komponen sel darah merah juga ikut terbuang. Semakin lama menstruasi berlangsung, maka semakin banyak pengeluaran dari tubuh. Hal tersebut mengakibatkan pengeluaran besi meningkatdan keseimbangan zat besi dalam tubuh terganggu. Menstruasi menyebabkan wanita kehilangan zat besi hingga dua kali jumlah kehilangan zat besi laki-laki. Apabila darah yang keluar saat menstruasi cukup banyak dan waktu menstruasi lebih lama dari normal, berarti jumlah zat besi yang hilang dari tubuh juga cukup besar. Setiap orang mengalami kehilangan darah dalam jumlah yang berbedabeda. Hal ini dipengaruhi oleh banyak factor seperti keturunan, keadaan kelahiran, dan besar tubuh. Saat menstruasi terjadi pengeluaran darah dari dalam tubuh. Hal ini menyebabkan zat besi yang terkandung dalam hemoglobin berkurang. Salah satu komponen sel darah merah juga ikut terbuang. Semakin lama menstruasi berlangsung, maka semakin banyak pengeluaran dari tubuh. Hal tersebut mengakibatkan pengeluaran besi meningkat dan keseimbangan zatbesi dalam tubuh terganggu.Menstruasimenyebabkan wanita kehilangan zat besi hingga dua kali jumlah kehilangan zat besi laki-laki. Apabila darah yang keluar saat menstruasi cukupbanyak, berartijumlahzatbesi yang hilang dari tubuh juga cukup besar. 
Setiap orang mengalami kehilangan darah dalam jumlah yang berbeda-beda. Hal ini dipengaruhi oleh banyak factor seperti keturunan, keadaan kelahiran, dan besar tubuh. (Briawan, 2014).

Hasil penelitian ini sejalan dengan hasil penelitian Reni (2016) dengan judul “Gambaran Lama Menstruasi Dan Status Gizi Dengan Kejadian Anemia Pada Remaja Putri Di Smk Bina Cipta Palembang Tahun 2016", menyimpulkan bahwa dari kelompok responden yang mengalami anemia baik ringan sekali, ringan dan sedang sebagian besar adalah responden dengan lama menstruasi lebih dari7 hari yaitu 57,1\%, 37,5\% dan 85,7\%. Hasil penelitian ini juga sejalan dengan hasil penelitian Abdul dkk (2017) dengan jdudul "Faktor-Faktor Yang Berhubungan Dengan Kejadian Anemia Pada Remaja Putri”, menyimpulkan bahwa kejadian anemia paling banyak terjadi pada remaja yang memiliki lama menstruasi tidak normal yaitu lebih dari 7 hari dengan persentase sebesar 32\% dan dari hasil analisis hubungan lama menstruasi dengan kejadian anemia.

Berdasarkan hasil penelitian ini, peneliti berasumsi bahwa hampir seluruhnya remaja putri mengalami anemia dikarenakan lama menstruasi $>7$ hari (hipermenore). Oleh kerena itu, diperlukan dukungan dan kerjasama dengan tenaga kesehatan untuk memberikan pencegahan terhadap terjadinya anemia yaitu dengan cara memberikan tablet Fe kepada remaja putri.

\section{SIMPULAN}

Hampir setengahnya remaja putri di SMAN 1 Parongpong mengalami kejadian anemia ringan, sebagian besar remaja putri di SMAN 1 Parongpong mengalami anemia ringan dengan IMT underweight (kurus), dan hampir seluruhnya remaja putri di SMAN 1 Parongpong mengalami anemia ringan dengan lama menstruasi lebih dari tujuh hari (hipermenore).

\section{SARAN}

Dari hasil penelitian ini diharapkan para remaja putri baik kelas X, XI, dan XII mengkonsumsi suplemen zat besi dan vitamin C. Memasitkan asupan makanan kaya zat besi tercukupI serta menghindari konsumsi teh dan kopi karena dapat menghambat penyerapan zat besi. Selain itu memberikan penyuluahan tentang TTD (Tablet Tambah Darah) yang 
dikonsumsi jika tidak menstruasi sebanyak 1 tablet dan saat menstruasi sebanyak 2 tablet. Diharapkan pihak sekolah dapat menyediakan sarana dan prasarana untuk melakukan konseling sehingga dapat mencegah terjadinya anemia pada remaja putri dan dapat mengobati anemia yang telah terjadi pada remaja putri. Selain itu pihak sekolah harus menyediakan sarana dan prasarana untuk siswa-siswinya jika ada keluhan yang berhubungan dengan kesehatan. Dan diharapkan dapat sering melakukan penyuluhan kesehatan terutama mengenai anemia pada remaja khususnya pada remaja putri di SMAN 1 Parongpong atau sekolahan lainnya yang sangat rentan terkena anemia, agar mahasiswa dapat mengembangkan ilmu pengetahuan khususnya mahasiswa program studi DIII Kebidanan dengan terjun langsung ke lapangan.

\section{REFERENSI}

Almatsier, S. 2009. Prinsip Ilmu Gizi. Jakarta: PT Gramedia Pustaka Utama

Agria I, Ruri N.S, dan Icham. 2012. Gizi Reproduksi. Yogyakarta: Fitmaya

Arisman. 2010. Gizi dalam Daur Kehidupan Ed 2. Jakarta: EGC

Badriah, D.L. 2011. Gizi dalam Kesehatan Reproduksi. Bandung: PT Rafika Aditama

Basith A, Rismia A, dan Noor D. 2017. Faktor-Faktor yang Berhubungan dengan Kejadian

Anemia pada Remaja Putri di SMPN 4 Banjabaru. [Online]. Vol 5 nomor 1 halaman 110.

Tersedia:https://scholer.google.co.id/scholer=faktor+faktor+yang+berhubungan+dengan + kejadian+anemia+pada+remaja+putri+di+SMPN+4+Banjarbaru= [28 Februari 2019]

Briawan, D. 2014. Anemia Masalah Gizi pada Remaja Wanita. Jakarta: EGC

Cuningham, Levono, Bloom, Hauth, Rouse, dan Spong. 2012. Obstetri Williams Ed 23 Vol 2. Jakarta: EGC

Fikawati S, Ahmad S, dan Arianda V. 2017. Gizi Anak dan Remaja Ed 1. Depok: Rajawali Pers

Fraser D.M dan Margaret A.C. 2009. Myles Buku Ajar Kebidanan. Jakarta: EGC

Febrianti, Waras W.U, dan Adriana. 2013. Gambaran Lama Haid dan Kejadian Anemia pada Remaja Putri di MAN 2 Bogor. [Online]. VOL 1 Nomor 1 halaman 11-15. Tersedia: https://scholer.google.co.id/scholer=gambaran+lama

+haid+dan+kejadian+anemia+pada+remaja+putri+di+MAN+2+Bogor= [28 Februari 2019] 
Handayani W dan Andi S.H. 2008. Asuhan Keperawatan pada Klien dengan Gangguan Sistem Hematologi. Jakarta: Salemba Medika

Helen, V. 2008. Buku Ajar Asuhan Kebidanan. Jakarta: EGC

Hernawati E dan Lia K. 2017. Buku Ajar Bidan Kegawatdaruratan Maternal dan Neonatal. Jakarta: TIM

Irianto, K. 2015. Kesehatan Reproduksi. Bandung: Alfabeta

Istianty A dan Suryono. 2010. Gizi Terapan. Bandung: PT Remaja Rosdakarya

Kaimudin N.I, Hariati L, dan Jusniar R.A. 2017. GambaranSkrining dan determinan Kejadian Anemia pada Remaja Putri di SMAN 3 Kendari. [Online]. Vol 2 Nomor 2 halaman $1-10$. Tersedia: https://scholer.google.co.id/scholer=gambaran+skrining+dan+determinan+kejadian+ane $\underline{\text { mia+pada+remaja+putri+di+SMAN+3+Kendari }}=$ [28 Februari 2019]

Kementerian Kesehatan Republik Indonesia. 2013. Anemia pada Remaja. Jakarta: Kemenkes RI

Kementerian Kesehatan Republik Indonesia. 2016. Data Formatif Anemia pada Remaja Putri. Jakarta: Kemenkes RI

Kementerian Kesehatan Republik Indonesia. 2017. Profil Kesehatan Indonesia tahun 2016. Jakarta: Kemenkes RI

Kementerian Kesehatan Republik Indonesia. 2017. Profil Kesehatan Jawa Barat tahun 2016. Jakarta: Kemenkes RI

Kumalasari I dan Iwan A. 2014. Kesehatan Reproduksi untuk Mahasiswa Kebidanan dan Keperawatan. Jakarta: Salemba Medika

Kusmiran, E. 2014. Kesehatan Reproduksi Remaja dan Wanita. Bandung: STIKes Rajawali Kriebs J.M dan Garolyn L Geger. 2009. Asuhan Kebidanan Verney Ed 2. Jakarta: EGC

Manuaba I.A.C, Ida B.G.F.M, dan Ida B.G.M. 2010. Ilmu Kebidanan, Penyakit Kandungan, dan KB. Jakaerta: EGC

Marcdante K.J, Robert M.K, Hal B.J, dan Richard E.B. 2011. Nelson Ilmu Kesehatan Anak Esensial. Jakarta: IDAI

Notoatmodjo, S. 2010. Metodologi Penelitian Kesehatan. Jakarta: Rineka Cipta

Proverawati A dan Asfuah S. 2009. Gizi untuk Kebidanan. Yogyakarta: Nuha Medika

Riset Kesehatan Daerah. 2013. Anemia di Jawa Barat. Jakarta: Rikesda

Riset Kesehatan Daerah. 2013. Penanggulangan Pemerintah terhadap Anemia pada Remaja. Jakarta: Rikesda 
Saswita, R. 2016. Gambaran Lama Menstruasi dan Status Gizi dengan Kejadian Anemia pada Remaja Putri di SMK Bina Cipta Palembang. [Online]. Vol 1 nomor 1 halaman 1118

Tersedia:

https://scholer.google.co.id/scholer=gambaran+lama+menstruasi+dan+status+gizi+denga

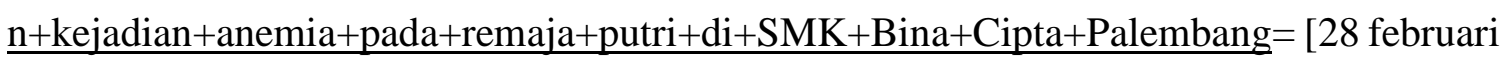
2019]

Setiawan, A dan Suryono. 2010. Metodologi Penelitian Kebidanan. Jakarta: Nuha Medika

Shariff S.A dan Nurlina A. 2018. Hubungan antara Status Gizi dan Pola Menstruasi dengan Kejadian Anemia pada Mahasiswi Prodi DIII Kebidanan Universitas Muslim Indonesia.[Online]. $\quad$ Vol 1 nomor 1 halaman34-39. Tersedia: https://scholer.google.co.id/scholer=hubungan+antara+status+gizi+dan+pola+menstruasi +dengan+kejadian+anemia+pada+mahasiswi+prodi+DIII+Kebidanan+Universitas+Musl $\underline{\mathrm{im}+\text { Indonesia }}=[28$ Februari 2019]

Soetjiningsih, dan Gde R. 2015. Tumbuh Kembang Anak Ed 2. Jakarta: EGC

Soetjiningsih. 2010. Tumbuh Kembang Remaja dan Permasalahannya. Jakarta: CV Sagung Seto

Sugiyono. 2016. Metode Penelitian Kuantitatif, Kualitatif, dan R\&D. Bandung: PT Alfabeta Supanasa I.D.N, Bachyar B, dan Ibnu F. 2016. Penilaian Status Gizi. Jakarta: EGC

World Health Organization. 2015. Pengertian Remaja. [Online]. Tersedia: https://www.who. .pengertian-remaja//[08 Februari 2019]

World Health Organization. 2014. Klasifikasi Remaja. [Online]. Tersedia: https://www.who.klasifikasi-remaja//[08 Februari 2019]

World Health Organization. 2013. Masalah Kesehatan Remaja. [Online]. Tersedia: https://www.who.masalah-kesehatan.remaja//[08 Februari 2019]

World Health Organization. 2013. Prevelensi Anemia. [Online]. Tersedia: https://www.who.prevelensi-anemia// [08 Februari 2019 